\title{
Pharmacogenomic Identification of c-Myc/Max-Regulated Genes Associated with Cytotoxicity of Artesunate towards Human Colon, Ovarian and Lung Cancer Cell Lines
}

\section{Serkan Sertel ${ }^{1,2,3}$, Tolga Eichhorn ${ }^{2,3}$, Christian H. Simon ${ }^{1}$, Peter K. Plinkert ${ }^{1}$, Steven W.} Johnson ${ }^{4}$ and Thomas Efferth ${ }^{2,3}$ *

1 Department of Otorhinolaryngology, Head \& Neck Surgery, University of Heidelberg, Im Neuenheimer Feld 400, 69120 Heidelberg, Germany

2 German Cancer Research Center, Pharmaceutical Biology (C015), Im Neuenheimer Feld 280, 69120 Heidelberg, Germany

3 Department of Pharmaceutical Biology, Institute of Pharmacy and Biochemistry, University of Mainz, Staudingerweg 5, 55099 Mainz, Germany

4 Department of Pharmacology, University of Pennsylvania Cancer Center, Philadelphia, PA 191046160, USA

* Author to whom correspondence should be addressed; E-Mail: efferth@uni-mainz.de.

Received: 26 March 2010; in revised form: 20 April 2010 / Accepted: 22 April 2010 /

Published: 22 April 2010

Abstract: Development of novel therapy strategies is one of the major pressing topics of clinical oncology to overcome drug resistance of tumors. Artesunate (ART) is an antimalarial drug, which also exerts profound cytotoxic activity towards cancer cells. We applied a gene-hunting approach using microarray-based transcriptome-wide mRNA expression profiling and COMPARE analyses. We identified a set of genes, whose expression was associated either with high $\mathrm{IC}_{50}$ values or low $\mathrm{IC}_{50}$ values for ART. Therefore, these genes may function as resistance or sensitivity factors for response of tumor cells towards ART. This viewpoint is conceivable for genes involved in ribosomal activity, drug transport, cellular antioxidant defense, apoptosis, cell proliferation, cell cycle progression etc. An investigation of underlying signal transduction by pathway analysis suggested a role of the signaling pathways related to tumor necrosis factor (TNF) and the tumor suppressor p53. On the other hand, there were genes without obvious functional link to cellular response to ART, such as genes involved in the survival of cochlear outer and inner hair cells etc. We proved the hypothesis that ART influences the activity of 
transcription factors regulating downstream genes involved or not involved in response of cancer cells towards ART. This would explain the identification of genes with and without obvious relation to the cytotoxic activity of ART by microarray and COMPARE analyses. By analysis of the binding motifs for the transcription factors c-Myc and Max, we indeed found that 53 of 56 genes contained one or more binding sites for c-Myc/Max upstream of the gene-location. We conclude that c-Myc and Max-mediated transcriptional control of gene expression might contribute to the therapeutic effects of ART in cancer cells, but may also confer unwanted side effects by affecting therapy-unrelated genes.

Keywords: Artesunate (ART); clinical oncology; chemotherapeutic resistance; microarray; expression profiling; pathway analysis

\section{Abbreviations:}

\begin{tabular}{|c|c|c|}
\hline $\mathrm{ABC}$ & $=$ & ATP-binding cassette transporter \\
\hline ACT & $=$ & artemisinin-based combination therapy \\
\hline ART & $=$ & artesunate \\
\hline CYP & $=$ & cytochrome $\mathrm{P} 450$ \\
\hline DEPC & $=$ & diethylpyrocarbonat \\
\hline DMSO & $=$ & dimethylsulfoxide \\
\hline EGFR & $=$ & Epidermal Growth Factor Receptor \\
\hline iNOS & $=$ & inducible nitric oxide synthase \\
\hline IPA & $=$ & Ingenuity Pathway Analysis \\
\hline LPS & $=$ & lipopolysaccharide \\
\hline MAX & $=$ & Myc-associated factor $\mathrm{x}$ \\
\hline MDR & $=$ & multidrug resistance \\
\hline MTT & $=$ & 3-(4,5-dimethyl-thizol-2-yl)-2,5-diphenyltetrazolium bromide \\
\hline NCI & $=$ & National Cancer Institute \\
\hline $\mathrm{NF}-\kappa \mathrm{B}$ & $=$ & nuclear factor 'kappa-light-chain-enhancer' of activated B-cells \\
\hline NSCLC & $=$ & non-small cell lung cancer \\
\hline PCR & $=$ & polymerase chain reaction \\
\hline PDK & $=$ & pyruvate dehydrogenase kinase \\
\hline Pgp & $=$ & P-glycoprotein \\
\hline PI3K & $=$ & phosphatidylinositol 3'-kinase \\
\hline PK & $=$ & protein kinase \\
\hline $\mathrm{PKC}$ & $=$ & protein kinase $\mathrm{C}$ \\
\hline ROS & $=$ & reactive oxygen species \\
\hline qRT-PCR & $=$ & quantitative real-time PCR \\
\hline SDS & $=$ & sodium dodecyl sulphate \\
\hline $\mathrm{SSC}$ & $=$ & standard saline citrate \\
\hline $\mathrm{TCM}$ & $=$ & traditional Chinese medicine \\
\hline TGF- $\beta 1$ & $=$ & transforming growth factor-beta 1 \\
\hline
\end{tabular}


TNF $\quad=\quad$ tumor necrosis factor

WHO $\quad=\quad$ World Health Organization

\section{Introduction}

Artemisia annua L. (Chinese: qīnghāo), also known as sweet annie, sweet sagewort or armoise annuelle, is used in traditional Chinese medicine (TCM) for the treatment of fever and chills [1]. In 1972, Prof. Tu Youyou (Chinese Academy of Traditional Chinese Medicine, Beijing, China), identified artemisinin (qīnghāosu) as the active anti-malarial constituent of Artemisia annua L. [2,3]. Artemisinin is a sesquiterpene lactone with an internal peroxide bridge essential for its activity towards Plasmodium falciparum and Plasmodium vivax [1,4]. In fact, the World Health Organization (WHO) has officially recommended artemisinin and its derivatives for the treatment of malaria, particularly as a part of combination therapies with other anti-malarial drugs (artemisinin-based combination therapies, ACTs).

In the past dozen of years, we have systematically analyzed medicinal plants used in TCM for phytochemicals with cytotoxic activity towards cancer cells [5-9] Among a huge panel of natural products, we found that the artemisinin and its derivative artesunate (ART) also reveal profound anticancer activity in vitro and in vivo [4,6-8,10-15]. So far, their mechanisms of anti-cancer action have not completely been understood.

In the present investigation, we used microarray technology in order to disclose all genes involved at the transcriptional level. We subjected this expression profile to a signaling pathway analysis. Furthermore, we performed a transcription factor analysis, which indicated a possible role of c-Myc and Max as transcriptional regulators for downstream genes determining the response of cancer cells towards ART.

\section{Results}

\subsection{Cytotoxicity of cell lines}

The mean $50 \%$ inhibition concentration $\left(\mathrm{IC}_{50}\right)$ for ART in colon cancer cell lines was $5.9 \pm 5.8 \mu \mathrm{M}$ (Figure 1A), in non-small cell lung cancer $9.2 \pm 8.5 \mu \mathrm{M}$ (Figure 1B), and in ovarian cancer cell lines $6.7 \pm 7.8 \mu \mathrm{M}$ (Figure 1C). To investigate the activity of ART in drug-resistant cell lines, ovarian cancer cells selected for resistance towards cisplatin, adriamycin, or paclitaxel were used (Figure 1D). While all cisplatin-resistant sublines were similar or more sensitive towards ART than the parental 2008 cell line, adriamycin- or paclitaxel-resistant A2780 cells were cross-resistant towards ART as compared to their drug-sensitive counterpart (Figure 1D). 
Figure 1. Ranked order of $\mathrm{IC}_{50}$ values for $\mathrm{ART}$ in 39 human cell lines of three different anatomical locations. (A) Colon cancer cell lines, (B) non-small cell lung cancer (NSCLC) cell lines, (C) ovarian cancer cell lines, and (D) sensitive ovarian cell lines and sublines resistant to cisplatin, adriamycin, or paclitaxel.
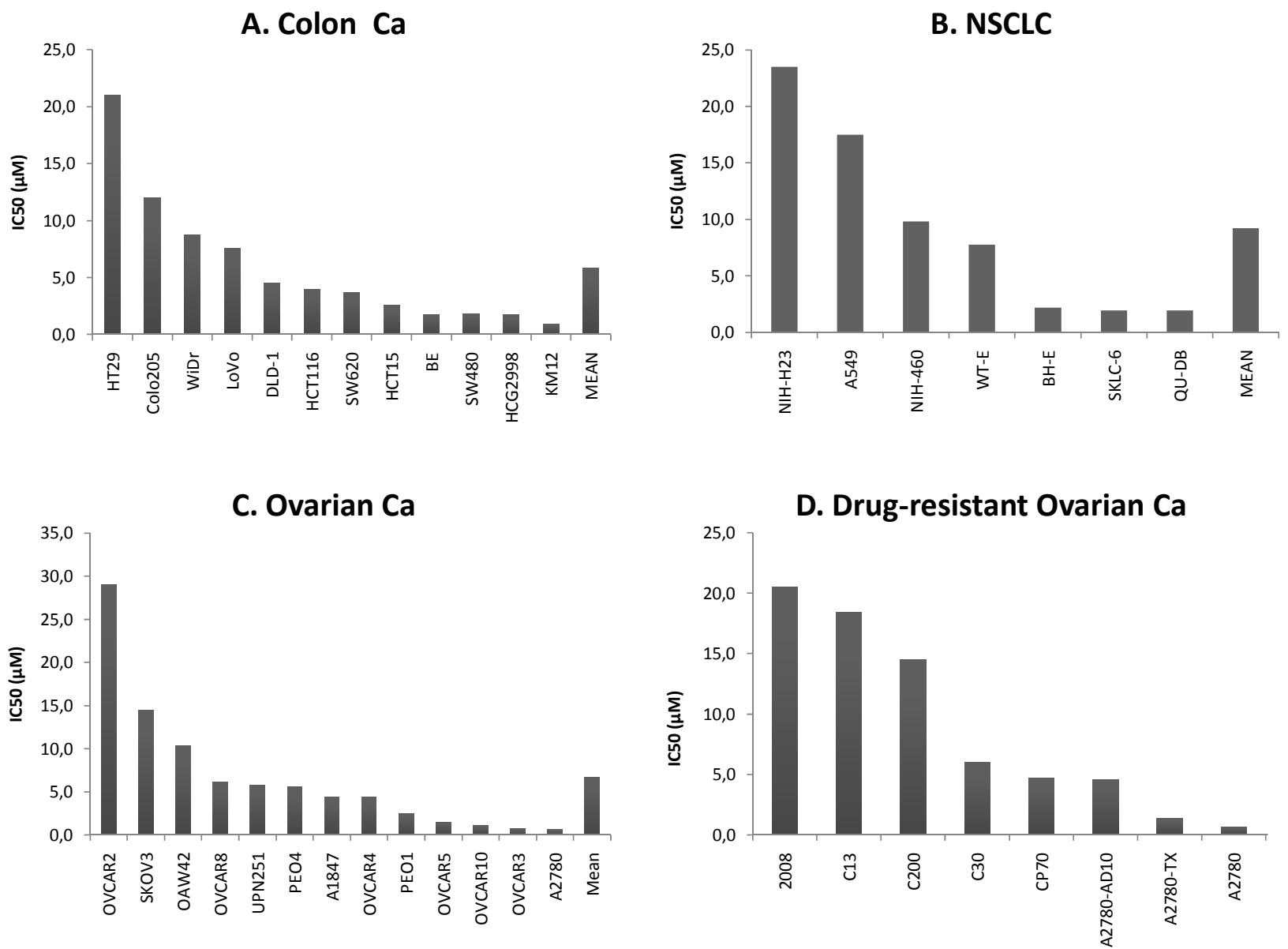

\subsection{Microarray hybridization}

A pharmacogenomic approach was applied to explore novel molecular determinants of sensitivity and resistance to ART. We determined the transcriptome-wide mRNA expression of 39 tumor cell lines and correlated the expression data with the $\mathrm{IC}_{50}$ values for ART. This represents a hypothesisgenerating approach, which allows the identification of novel putative molecular determinants of cellular response towards ART. We performed COMPARE analyses of the $\mathrm{IC}_{50}$ values for ART and the microarray-based mRNA expression levels. First, we performed a standard COMPARE analysis, in which cell lines that were most inhibited by ART (lowest $\mathrm{IC}_{50}$ values) were correlated with the lowest mRNA expression levels of genes. These genes may be considered as possible candidate genes, which determine cellular resistance to ART. Afterwards, a reverse COMPARE analysis was performed: the most inhibited cell lines were correlated with the highest gene expression levels, indicating possible drug sensitivity genes. Only correlations with a correlation coefficient of $\mathrm{R}>0.3$ (standard COMPARE) or R > -0.3 (reverse COMPARE) were considered (Table 1).

Among the genes identified by this approach were genes from diverse functional groups such as structural constituents of ribosomes (RPL29), ATP-binding cassette (ABC) transporters (ABCC3), 
kinases (PRKCSH, ITPK1, IKBKG, DDR2), cellular antioxidant defense and carcinogenesis (ATOX1), organization of actin cytoskeleton (RRAS), carcinogenesis (SMAD3, WNT7A), cell adhesion and growth of malignant cells (ST8SIA1), apoptosis and cell proliferation $(C S E 1 L)$, cell cycle progression and differentiation (S100A10) and metastasis (HMGA1, RPSA).

Table 1. Genes determining sensitivity or resistance towards ART in the panel of 39 cell lines as identified by microarray mRNA expression profiling and COMPARE analysis.

\begin{tabular}{|c|c|c|c|c|}
\hline \multicolumn{5}{|c|}{ RESISTANCE GENES } \\
\hline Gene & UNIQID & Pearson & Name & Function \\
\hline SLC30A1 & R31110 & 0.552 & Human hbc647 mRNA sequence & Involved in zinc transport out of the cell. \\
\hline GFAP & AA069414 & 0.552 & Glial fibrillary acidic protein & Class-III intermediate filament \\
\hline$B D K R B 2$ & AA194043 & 0.513 & Bradykinin receptor B2 & Receptor for bradykinin \\
\hline$A K R 1 C 3$ & AA916325 & 0.511 & $\begin{array}{l}\text { Aldo-keto reductase family } 1, \\
\text { member C3 }\end{array}$ & $\begin{array}{l}\text { Member of the aldo/keto reductase } \\
\text { superfamily }\end{array}$ \\
\hline SNAP23 & N32278 & 0.472 & $\begin{array}{l}\text { Synaptosomal-associated protein, } \\
23 \mathrm{kD}\end{array}$ & $\begin{array}{l}\text { Regulator of membrane fusion } \\
\text { machinery and transport vesicle docking }\end{array}$ \\
\hline$K Y N U$ & H87471 & 0.471 & $\begin{array}{l}\text { Kynureninase (L-kynurenine } \\
\text { hydrolase) }\end{array}$ & $\begin{array}{l}\text { Cleaves L-kynurenine and L-3- } \\
\text { hydroxykynurenine }\end{array}$ \\
\hline$A K R 1 C 1$ & R93124 & 0.453 & $\begin{array}{l}\text { Aldo-keto reductase family } 1 \text {, } \\
\text { member } \mathrm{C} 1\end{array}$ & $\begin{array}{l}\text { Member of the aldo/keto reductase } \\
\text { superfamily }\end{array}$ \\
\hline ITPK1 & AA463931 & 0.452 & $\begin{array}{l}\text { Inositol 1,3,4-triphosphate 5/6 } \\
\text { kinase }\end{array}$ & $\begin{array}{l}\text { Phosphorylates various inositol } \\
\text { polyphosphates }\end{array}$ \\
\hline not specified & $\mathrm{H} 44051$ & 0.443 & not specified & Member of the keratin family \\
\hline$A L D H 3 A 1$ & AA069024 & 0.435 & $\begin{array}{l}\text { Aldehyde dehydrogenase } 3 \text { family, } \\
\text { member A1 }\end{array}$ & $\begin{array}{l}\text { ALDH oxidizes various aldehydes to the } \\
\text { corresponding acids. }\end{array}$ \\
\hline GYS2 & N52282 & 0.432 & Glycogen synthase 2 (liver) & $\begin{array}{l}\text { Transfers the glycosyl residue from } \\
\text { UDP-Glc to the non-reducing end of } \\
\text { alpha-1,4-glucan }\end{array}$ \\
\hline KRT4 & AA629189 & 0.425 & Keratin 4 & Member of the keratin gene family \\
\hline$C D 24$ & H59916 & 0.423 & $\begin{array}{l}\text { CD24 antigen (small cell lung } \\
\text { carcinoma) }\end{array}$ & $\begin{array}{l}\text { Signal transducer; modulates B-cell } \\
\text { activation }\end{array}$ \\
\hline SMAD3 & W72201 & 0.423 & $\begin{array}{l}\text { Similar to mothers against } \\
\text { decapentaplegic homolog } 3\end{array}$ & $\begin{array}{l}\text { Transcriptional modulator; plays a role } \\
\text { in carcinogenesis }\end{array}$ \\
\hline CREB3L3 & AI952482 & 0.415 & Sirtuin 6 & Glycosyl transferase activity \\
\hline SLC12A7 & AA427732 & 0.402 & $\begin{array}{l}\text { Solute carrier } 12 \\
\text { (potassium/chloride transporters) }\end{array}$ & $\begin{array}{l}\text { Important for the survival of cochlear } \\
\text { outer and inner hair cells }\end{array}$ \\
\hline$S L C 22 A 5$ & AI933276 & 0.398 & $\begin{array}{l}\text { Solute carrier } 22 \text { (organic cation } \\
\text { transporter) }\end{array}$ & $\begin{array}{l}\text { Involved in the active cellular uptake of } \\
\text { carnitine. }\end{array}$ \\
\hline FETUB & AA705308 & 0.396 & Fetuin B & Member of the fetuin family \\
\hline TRAM1 & H15707 & 0.366 & $\begin{array}{l}\text { Translocating chain-associating } \\
\text { membrane protein }\end{array}$ & $\begin{array}{l}\text { Translocation of secretory proteins } \\
\text { across the ER membrane }\end{array}$ \\
\hline WNT7A & AI885451 & 0.365 & $\begin{array}{l}\text { Wingless-type MMTV integration } \\
\text { site family }\end{array}$ & Involved in oncogenesis \\
\hline$D C D C 2$ & AA127741 & 0.360 & Doublecortin domain containing 2 & Enhances microtubule polymerization \\
\hline
\end{tabular}


Table 1. Cont.

\begin{tabular}{|c|c|c|c|c|}
\hline Gene & UNIQID & Pearson & Name & Function \\
\hline ERRFII & AA400258 & 0.359 & Gene 33/Mig-6 & Involved in cell signaling and cell stress \\
\hline$A B C C 3$ & AA429895 & 0.357 & $\begin{array}{l}\text { ATP-binding cassette, sub-family C } \\
\text { (CFTR/MRP) }\end{array}$ & $\begin{array}{l}\text { Member of the superfamily of ABC- } \\
\text { Transporters }\end{array}$ \\
\hline$I K B K G$ & R56102 & 0.357 & $\begin{array}{l}\text { Homo sapiens cDNA FLJ20586 fis, } \\
\text { clone KAT09466 }\end{array}$ & $\begin{array}{l}\text { Regulatory subunit of the inhibitor of } \\
\text { kappaB kinase (IKK) }\end{array}$ \\
\hline S100A10 & AA444051 & 0.354 & S100 calcium-binding protein A10 & $\begin{array}{l}\text { Regulation of cellular processes such as } \\
\text { cell cycle progression and differentiation }\end{array}$ \\
\hline GSR & AA777289 & 0.352 & Glutathione reductase & $\begin{array}{l}\text { Maintains high levels of reduced } \\
\text { glutathione in the cytosol }\end{array}$ \\
\hline ST8SIA1 & AA169183 & 0.349 & Sialyltransferase $8 \mathrm{~A}$ & $\begin{array}{l}\text { Cell adhesion and growth of cultured } \\
\text { malignant cells }\end{array}$ \\
\hline CUL5 & AA086475 & 0.337 & Cullin 5 & $\begin{array}{l}\text { May form a cell surface vasopressin } \\
\text { receptor }\end{array}$ \\
\hline$S C A P$ & R54823 & 0.335 & Srebp cleavage-activating protein & Regulates sterol biosynthesis \\
\hline$A K R 1 B 1$ & AA701963 & 0.330 & $\begin{array}{l}\text { Aldo-keto reductase family } 1 \text {, } \\
\text { member B1 }\end{array}$ & $\begin{array}{l}\text { Member of the aldo/keto reductase } \\
\text { superfamily }\end{array}$ \\
\hline$A T P 1 B 1$ & AA598814 & 0.329 & $\begin{array}{l}\text { ATPase, } \mathrm{Na}+/ \mathrm{K}+\text { transporting, beta } \\
1 \text { polypeptide }\end{array}$ & $\begin{array}{l}\text { Catalyzes ATP hydrolysis and ion } \\
\text { exchange across plasma membranes }\end{array}$ \\
\hline$V C A N$ & AA101875 & 0.326 & $\begin{array}{l}\text { Chondroitin sulfate proteoglycan } 2 \\
\text { (versican) }\end{array}$ & $\begin{array}{l}\text { May play a role in intercellular } \\
\text { signaling, cell mobility and } \\
\text { differentiation }\end{array}$ \\
\hline TRIM21 & N45131 & 0.309 & $\begin{array}{l}\text { Sjögren syndrome antigen A1, } \\
\text { tripartite motif-containing } 21\end{array}$ & $\begin{array}{l}\text { Ribonucleoprotein particle which binds } \\
\text { DNA, RNA, protein and zinc }\end{array}$ \\
\hline$G L R X$ & AA291163 & 0.307 & Glutaredoxin (thioltransferase) & $\begin{array}{l}\text { Reduces low molecular weight } \\
\text { disulfides and proteins }\end{array}$ \\
\hline SLC23A1 & AI934925 & 0.306 & $\begin{array}{l}\text { Solute carrier family } 23 \text { (nucleobase } \\
\text { transporters) }\end{array}$ & $\begin{array}{l}\text { This gene encodes one of the Vitamin C } \\
\text { transporters }\end{array}$ \\
\hline \multicolumn{5}{|c|}{ SENSITIVITY GENES } \\
\hline Gene & UNIQID & Pearson & Name & Function \\
\hline RPL29 & AW073449 & -0.300 & Ribosomal protein L29 & $\begin{array}{l}\text { Cytoplasmic ribosomal protein of the } \\
60 \text { S subunit }\end{array}$ \\
\hline PSMB5 & AA864479 & -0.304 & $\begin{array}{l}\text { Proteasome (prosome, macropain) } \\
\text { subunit, } \beta \text { type }\end{array}$ & $\begin{array}{l}\text { May catalyze basal processing of } \\
\text { intracellular antigens }\end{array}$ \\
\hline$D D R 2$ & AA243749 & -0.308 & $\begin{array}{l}\text { Discoidin domain receptor family, } \\
\text { member } 2\end{array}$ & $\begin{array}{l}\text { Tyrosine kinase receptor mediating } \\
\text { fibroblast migration and proliferation }\end{array}$ \\
\hline$A S N S$ & AA894927 & -0.309 & Asparagine synthetase & Synthesis of asparagine \\
\hline$L D H B$ & AI969670 & -0.310 & Lactate dehydrogenase B & Oxidoreductase activity \\
\hline$R A D 23 A$ & H99170 & -0.310 & RAD23 homolog A (S. cerevisiae) & Molecular calcium binding chaperone \\
\hline CSE1L & N69204 & -0.312 & $\begin{array}{l}\text { Chromosome segregation } 1 \text { (yeast } \\
\text { homolog)-like }\end{array}$ & $\begin{array}{l}\text { May play a role in apoptosis and cell } \\
\text { proliferation }\end{array}$ \\
\hline
\end{tabular}


Table 1. Cont.

\begin{tabular}{|c|c|c|c|c|}
\hline Gene & UNIQID & Pearson & Name & Function \\
\hline INSIGI & H59620 & -0.314 & Insulin induced gene 1 & $\begin{array}{l}\text { May play a role in growth and } \\
\text { differentiation of tissues involved in } \\
\text { metabolic control }\end{array}$ \\
\hline PABPCP5 & AA486531 & -0.315 & $\begin{array}{l}\text { Poly(A)-binding protein, } \\
\text { cytoplasmic } 1\end{array}$ & $\begin{array}{l}\text { May be involved in translationally } \\
\text { coupled mRNA turnover }\end{array}$ \\
\hline ATOXI & AA418694 & -0.315 & $\begin{array}{l}\text { Antioxidant protein } 1 \text { (yeast) } \\
\text { homolog } 1\end{array}$ & May play a role in carcinogenesis \\
\hline \multirow[t]{2}{*}{ PRKCSH } & AA496810 & -0.316 & Protein kinase $\mathrm{C}$ substrate $80 \mathrm{~K}-\mathrm{H}$ & $\begin{array}{l}\text { Acidic phospho-protein known to be a } \\
\text { substrate for protein kinase C }\end{array}$ \\
\hline & AA878561 & -0.319 & $\begin{array}{l}\text { Ubiquitin A-52 residue ribosomal } \\
\text { protein product }\end{array}$ & Regulation of gene expression \\
\hline ISG15 & AA406020 & -0.319 & $\begin{array}{l}\text { Interferon-stimulated protein, } 15 \\
\mathrm{kDa}\end{array}$ & $\begin{array}{l}\text { May regulate proteins involved in the } \\
\text { release of prostaglandin F2-alpha (PGF) }\end{array}$ \\
\hline \multirow[t]{2}{*}{$\overline{E E F 2}$} & R43766 & -0.322 & $\begin{array}{l}\text { Eukaryotic translation elongation } \\
\text { factor } 2\end{array}$ & Essential factor for protein synthesis \\
\hline & R37276 & -0.322 & $\begin{array}{l}\text { Eukaryotic translation initiation } \\
\text { factor } 4 \text { gamma, } 1\end{array}$ & Recognition of the mRNA cap \\
\hline $\mathrm{PCDH17}$ & AA969048 & -0.326 & Protocadherin 17 & $\begin{array}{l}\text { May play a role for cell-cell connections } \\
\text { in the brain }\end{array}$ \\
\hline PHB2 & AA464567 & -0.328 & B-cell associated protein & Functions as an estrogen receptor \\
\hline TIMM17A & AA708446 & -0.335 & $\begin{array}{l}\text { Translocase of inner mitochondrial } \\
\text { membrane } 17\end{array}$ & $\begin{array}{l}\text { Translocation of transit proteins across } \\
\text { mitochondrial membrane }\end{array}$ \\
\hline$R R A S$ & AI368184 & -0.337 & $\begin{array}{l}\text { Related RAS viral (r-ras) oncogene } \\
\text { homolog }\end{array}$ & $\begin{array}{l}\text { Regulates the organization of the actin } \\
\text { cytoskeleton }\end{array}$ \\
\hline \multirow[t]{2}{*}{ SYNCRIP } & AA186327 & -0.338 & $\begin{array}{l}\text { Synaptotagmin binding, } \\
\text { cytoplasmic RNA binding protein }\end{array}$ & Involved in mRNA processing \\
\hline & AA448261 & -0.345 & $\begin{array}{l}\text { High-mobility group protein } \\
\text { isoforms I and } \mathrm{Y}\end{array}$ & $\begin{array}{l}\text { Gene transcription, integration of } \\
\text { retroviruses into chromosomes and } \\
\text { metastasis }\end{array}$ \\
\hline$R P L 18 A$ & W81118 & -0.356 & $\begin{array}{l}\text { EST, similar to human 60S } \\
\text { Ribosomal Protein L18A }\end{array}$ & unknown \\
\hline RPS10 & AI611010 & -0.357 & Ribosomal protein S10 & $\begin{array}{l}\text { Catalyzes protein synthesis. Variable } \\
\text { expression of this gene in colorectal } \\
\text { cancers }\end{array}$ \\
\hline$U B B$ & AW078798 & -0.358 & Ubiquitin B & Regulation of gene expression \\
\hline RPSA & AA629897 & -0.367 & $\begin{array}{l}\text { Laminin receptor } 1(67 \mathrm{kD}, \\
\text { ribosomal protein SA) } \\
\end{array}$ & $\begin{array}{l}\text { Up-regulation in cancer cells associated } \\
\text { with invasion and metastasis }\end{array}$ \\
\hline PRMT1 & N55480 & -0.381 & $\begin{array}{l}\text { HMT1 (hnRNP methyltransferase)- } \\
\text { like } 2\end{array}$ & Arginine methyltransferase \\
\hline LMAN1 & AA446103 & -0.386 & Lectin, mannose-binding, 1 & Type I integral membrane protein \\
\hline$Y B X 1$ & AA599175 & -0.418 & $\begin{array}{l}\text { Nuclease sensitive element binding } \\
\text { protein } 1\end{array}$ & May play a role in DNA repair \\
\hline
\end{tabular}

\subsection{Signaling pathway profiling}

As a next step, we employed a signaling pathway analysis to better understand the biological consequences of ART treatment. The genes identified by microarray and COMPARE analyses were subjected to Ingenuity Pathway Analysis (version 6.5). Two networks were found to be significant in that they contained more of the identified genes than expected by chance. The first network is associated with cell morphology, antigen presentation and cell-mediated immune response 
(Figure 2A). The second network is associated with nervous system development and function, and cellular assembly and organization (Figure 2B).

Figure 2. Network view of associated proteins created within Ingenuity Pathway Analysis software for visualizing molecular interrelationships. (A) TNF- $\alpha$ and TP53, (B) SKAP and GFAP associated proteins. Coloring is based on the expression values that were uploaded with the dataset. Gray indicates the molecule was part of the dataset. Lines connecting molecules indicate molecular relationships. Dashed lines indicate indirect interactions; solid lines indicate direct interactions. The style of the arrows indicates specific molecular relationships and the directionality of the interaction.

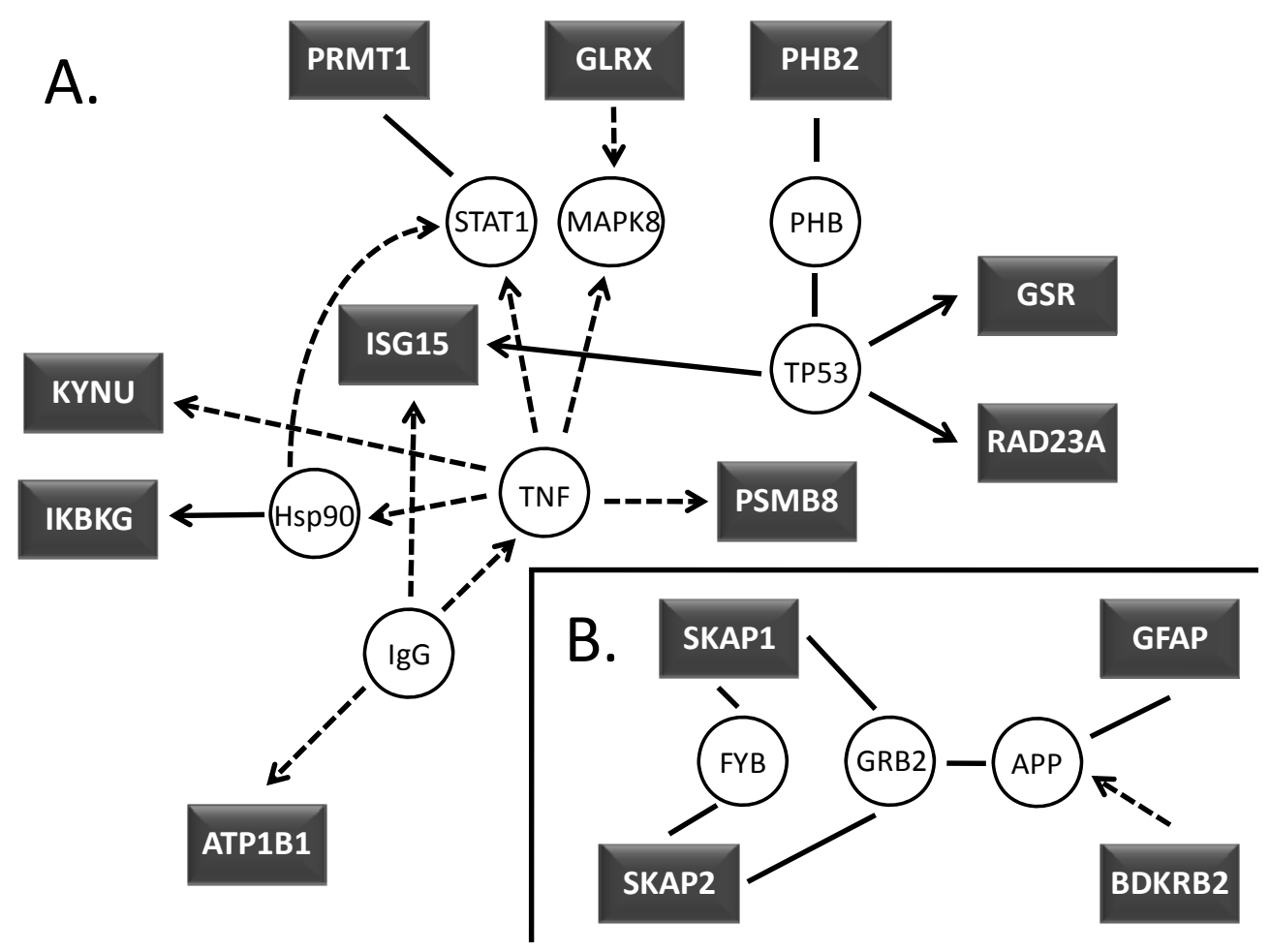

\subsection{Transcription factor downstream gene analyses}

In a previous investigation, we found a correlation between c-Myc expression and sensitivity towards ART [16], indicating that transcriptional regulation by c-Myc might play a role for mediating the cytotoxic effects of ART. By means of the ConSite program (http://www.phylofoot.org/consite/) for detection of transcription factor binding sites we now analyzed, whether the genes found in the present microarray analysis contained c-Myc binding motifs in their gene promoter sequences. Out of 56 genes, one gene has twelve, two genes have eleven, three genes nine, one gene eight, four genes seven, seven genes six, six genes five, five genes four, twelve genes three, five genes two potential binding sites, and seven genes have one potential binding site for c-Myc (Table 2). Remarkably, only three out of 56 gene promoters did not contain c-Myc binding motifs, indicating that transcriptional regulation by c-Myc might be an important determinant of cellular response towards ART. 
Table 2. Binding sequences of the transcription factor c-Myc upstream of genes identified by microarray mRNA expression profiling (+, 5' $-3^{\prime}$ strand;,$- 3^{\prime}-5^{\prime}$ strand).

\begin{tabular}{|c|c|c|c|}
\hline Gene & $\begin{array}{l}\text { Number of } \\
\text { potential } \\
\text { binding sites }\end{array}$ & Position (Score) & Strand \\
\hline SLC30A1 & 3 & $-2645(7,989),-910(8,955),-909(9,341)$ &,,++- \\
\hline GFAP & 2 & $-4972(8,199),-161(9,706)$ &,+- \\
\hline BDKRB2 & 7 & $\begin{array}{l}-4885(9,431),-4884(8,449),-3439(8,229),-2826(8,977),-2825 \\
(8,229),-1493(8,820),-1466(8,372)\end{array}$ &,,,,,+-++-+ \\
\hline AKR1C3 & 4 & $-3486(9,956),-3182(8,252),-1029(7,972),-71(9,667)$ &,,,+--- \\
\hline SNAP23 & 3 & $-4877(8,036),-857(8,449),-856(9,431)$ &,,-+- \\
\hline KYNU & \multicolumn{3}{|c|}{ No binding sites detected } \\
\hline AKR1C1 & 1 & $-4606(8,039)$ & + \\
\hline ITPK1 & 1 & $-2885(8,890)$ & - \\
\hline GYS2 & 1 & $-4280(8,960)$ & - \\
\hline KRT4 & 12 & $\begin{array}{l}-4540(9,810),-4539(8,393),-3905(8,504),-3532(9,421),-3531 \\
(10,337),-3442(8,372),-2264(9,431),-2263(8,449),-1942(10,480),- \\
1941(13,638),-1016(8,841),-165(9,118)\end{array}$ & $\begin{array}{l}+,+,-,+,-,+ \\
+,-,+,-,-,+\end{array}$ \\
\hline CD24 & 3 & $-2956(9,104),-2955(9,909),-2906(8,055)$ &,,+-- \\
\hline SMAD3 & 5 & $-3843(7,989),-3135(9,044),-2558(8,372),-418(9,341),-417(9,341)$ &,,,,---+- \\
\hline CREB3L3 & 9 & $\begin{array}{l}-4911(10,153),-3674(8,186),-32229(8,162),-2802(8,449),-2801 \\
(9,431),-2073(10,396),-1327(9,585),-485(9,431),-484(8,449) \\
\end{array}$ & $\begin{array}{l}-,+,+,+,-,+ \\
+,+,-\end{array}$ \\
\hline SLC12A7 & 11 & $\begin{array}{l}-4608(10,961),-4607(9,095),-2657(8,252),-2584(10,769),-2204 \\
(8,504),-1970(9,134),-1862(8,820),-1209(9,238),-1016(8,229),-61 \\
(10,468),-60(9,869)\end{array}$ & $\begin{array}{l}+,-,-,-,-,+,- \\
,-,-,+,-\end{array}$ \\
\hline SLC22A5 & \multicolumn{3}{|c|}{ No binding sites detected } \\
\hline FETUB & 6 & $\begin{array}{l}-3871(8,074),-1418(8,464),-804(10,572),-803(8,441),-418(9,706), \\
-69(9,983)\end{array}$ &,,,,,-++-+- \\
\hline TRAM1 & 3 & $-4348(8,890),-4347(9,552),-3118(8,515)$ &,,+-+ \\
\hline WNT7A & 3 & $-4745(9,706),-2862(9,491),-2664(8,960)$ &,,-++ \\
\hline DCDC2 & 1 & $-2660(8,259)$ & + \\
\hline ERRFI1 & 2 & $-4501(8,372),-4141(8,761)$ &,++ \\
\hline$A B C C 3$ & 5 & $\begin{array}{l}-4552(8,120),-4326(7,989),-4097(8,229),-4064(9,044),-4063 \\
(8,229)\end{array}$ &,,,,++++- \\
\hline IKBKG & 3 & $-952(9,431),-951(8,449),-543(9,421)$ &,,+-- \\
\hline S100A10 & 8 & $\begin{array}{l}-4729(8,687),-4728(9,828),-4050(8,178),-3913(10,807),-3912 \\
(9,350),-2303(9,666),-2272(8,449),-2271(9,431)\end{array}$ & $\begin{array}{l}+,-,+,+,-,- \\
+,-\end{array}$ \\
\hline GSR & 6 & $\begin{array}{l}-3066(9,667),-3065(8,199),-2431(9,726),-2043(8,017),-905 \\
(10,023),-904(8,229)\end{array}$ &,,,,,+---+- \\
\hline ST8SIA1 & 3 & $-3532(11,197),-3531(8,039),-2001(8,841)$ &,,+-+ \\
\hline CUL5 & 3 & $-4798(8,960),-643(8,504),-642(8,754)$ &,,++- \\
\hline SCAP & 2 & $-3904(8,449),-3903(9,431)$ &,+- \\
\hline AKR1B1 & 5 & $\begin{array}{l}-3654(8,372),-3594(8,820),-3429(9,409),-2950(8,229),-2636 \\
(8,960)\end{array}$ &,,,,-+--+ \\
\hline
\end{tabular}


Table 2. Cont.

\begin{tabular}{|c|c|c|c|}
\hline Gene & $\begin{array}{l}\text { Number of } \\
\text { potential } \\
\text { binding sites }\end{array}$ & Position (Score) & Strand \\
\hline ATP1B1 & 6 & $\begin{array}{l}-4514(11,479),-4513(10,785),-4151(9,902),-2867(9,095),-1545 \\
(8,252),-1136(8,960)\end{array}$ &,,,,,+--++- \\
\hline VCAN & 2 & $-1256(9,350),-224(8,055)$ &,+- \\
\hline TRIM21 & 7 & $\begin{array}{l}-3372(10,470),-3371(9,706),-2169(9,118),-2043(8,322),-407 \\
(8,055),-207(8,515),-206(10,627)\end{array}$ &,,,,,+-++++ \\
\hline GLRX & 7 & $\begin{array}{l}-2391(9,431),-2390(8,449),-1766(8,687),-1765(8,566),-1108 \\
(9,095),-1107(8,485),-115(8,213)\end{array}$ &,,,,,+-+-+- \\
\hline SLC23A1 & 3 & $-4955(8,047),-3370(12,419),-2782(8,372)$ &,,+-+ \\
\hline RPL29 & 7 & $\begin{array}{l}-4179(8,147),-2366(8,372),-703(9,552),-702(8,890),-624(9,277),- \\
593(8,449),-592(9,431)\end{array}$ &,,,,,,--+--+- \\
\hline PSMB5 & 6 & $\begin{array}{l}-3113(8,449),-3112(9,431),-1295(9,431),-1294(8,449),-1105 \\
(9,431),-1104(8,449)\end{array}$ &,,,,,+-+-+- \\
\hline ASNS & 3 & $-4092(9,277),-2283(9,104),-2087(10,491)$ &,,+-+ \\
\hline$\angle D H B$ & 4 & $-4479(9,491),-830(9,902),-563(9,431),-562(8,449)$ &,,,-++- \\
\hline RAD23A & 5 & $-2525(8,449),-2524(9,431),-156(9,095),-155(11,278),-37(8,607)$ &,,,,+-+-- \\
\hline INSIG1 & 5 & $\begin{array}{l}-4207(8,252),-3881(8,259),-3535(8,687),-2754(9,421),-161 \\
(8,754)\end{array}$ &,,,,+--+- \\
\hline PABPCP5 & 3 & $-1789(8,449),-1788(9,431),-454(9,341)$ &,,+-+ \\
\hline ATOX1 & 9 & $\begin{array}{l}-4359(8,199),-4358(11,356),-2830(9,134),-2656(9,706),-2618 \\
(8,017),-2313(9,431),-2312(8,449),-947(9,949),-121(9,956) \\
\end{array}$ & $\begin{array}{l}+,-,+,+,+,+, \\
-,-\end{array}$ \\
\hline PRKCSH & 9 & $\begin{array}{l}-4688(8,372),-4621(9,491),-3737(9,431),-3736(8,449),-2854 \\
(10,889),-2765(8,298),-2764(10,092),-121(8,830),-120(11,519) \\
\end{array}$ & $\begin{array}{l}-,-,+,-,+,+ \\
-,+,-\end{array}$ \\
\hline ISG15_ & 5 & $\begin{array}{l}-3964(9,431),-3963(8,449),-1932(10,627),-1931(12,578),-1603 \\
(8,218)\end{array}$ &,,,,+-+-- \\
\hline EEF2 & 6 & $\begin{array}{l}-3734(10,572),-3278(9,552),-3277(8,890),-2791(9,431),-2790 \\
(8,449),-1565(8,515)\end{array}$ &,,,,,-+-+-- \\
\hline PCDH17 & 1 & $-501(8,199)$ & - \\
\hline TIMM17A & 11 & \begin{tabular}{|l|}
$-3771(8,047),-3657(8,952),-2621(9,431),-2620(8,449),-2157$ \\
$(8,923),-1445(9,431),-1444(9,552),-1084(9,431),-623(9,431),-622$ \\
$(8,449),-170(8,047)$
\end{tabular} & $\begin{array}{l}+,+,+,-,+,+ \\
-,+,+,-,+\end{array}$ \\
\hline RRAS & 4 & $-4729(8,055),-3576(9,104),-3575(8,441),-230(10,403)$ &,,,-+-+ \\
\hline SYNCRIP & 4 & $-4703(7.977),-1609(10,480),-1608(12,721),-77(8,607)$ &,,,++-- \\
\hline RPS10 & 2 & $-3402(7,980),-1980(7,980)$ &,+- \\
\hline$U B B$ & 4 & $-4351(9,431),-4350(8,449),-1719(8,305),-1268(9,350)$ &,,,+--+ \\
\hline RPSA & & No binding sites detected & \\
\hline PRMT1 & 6 & $\begin{array}{l}-4832(8,305),-4831(8,372),-4430(8,441),-1711(8,393),-763 \\
(10,153),-762(9,706)\end{array}$ &,,,,,+-+-+- \\
\hline LMAN1 & 1 & $-511(8,444)$ & - \\
\hline YBX1 & 6 & $\begin{array}{l}-3039(8,464),-2000(9,585),-1590(8,960),-1589(9,277),-848 \\
(11,455),-847(10,755)\end{array}$ &,,,,,-++-+- \\
\hline
\end{tabular}


Since the transcriptional regulation of c-Myc is activated by binding of c-Myc to its dimerization partner, max, we correlated the microarray-based mRNA expression of c-Myc and Max, with the $\mathrm{IC}_{50}$ values for ART of our panel of cell lines in comparison to the cell line panel of the National Cancer Institute (NCI), USA. As shown in Figure 3A, there was no significant correlation between $\mathrm{IC}_{50}$ values for ART and c-Myc mRNA expression in our cell line panel $(P=0.3117, R=0.13815)$. In contrast, in the NCI cell line panel there was a significant inverse correlation $\left(P=1.12 \times 10^{-5}, R=-0.53825\right)$ between $\mathrm{IC}_{50}$ values for ART and c-Myc mRNA expression (Figure 3B). Interestingly, we observed an inverse correlation between max mRNA expression and $\mathrm{IC}_{50}$ values for ART in both cell line panels (our cell line: $P=0.00271, R=-0.67838$; NCI cell line: $P=3.19 \times 10^{-4}, R=-0.44621$ ) (Figure 3C and D).

Figure 3. Linear regression of $\mathrm{IC}_{50}$ values for $\mathrm{ART}$ and mRNA expression of c-Myc (A) and $\operatorname{Max}(\mathrm{C})$ in our cell lines and linear regression of $\log _{10} \mathrm{IC}_{50}$ values for ART and mRNA expression of c-Myc (B) and Max (D) in the NCI cell line panel. Significance levels were calculated using Pearson's correlation test.
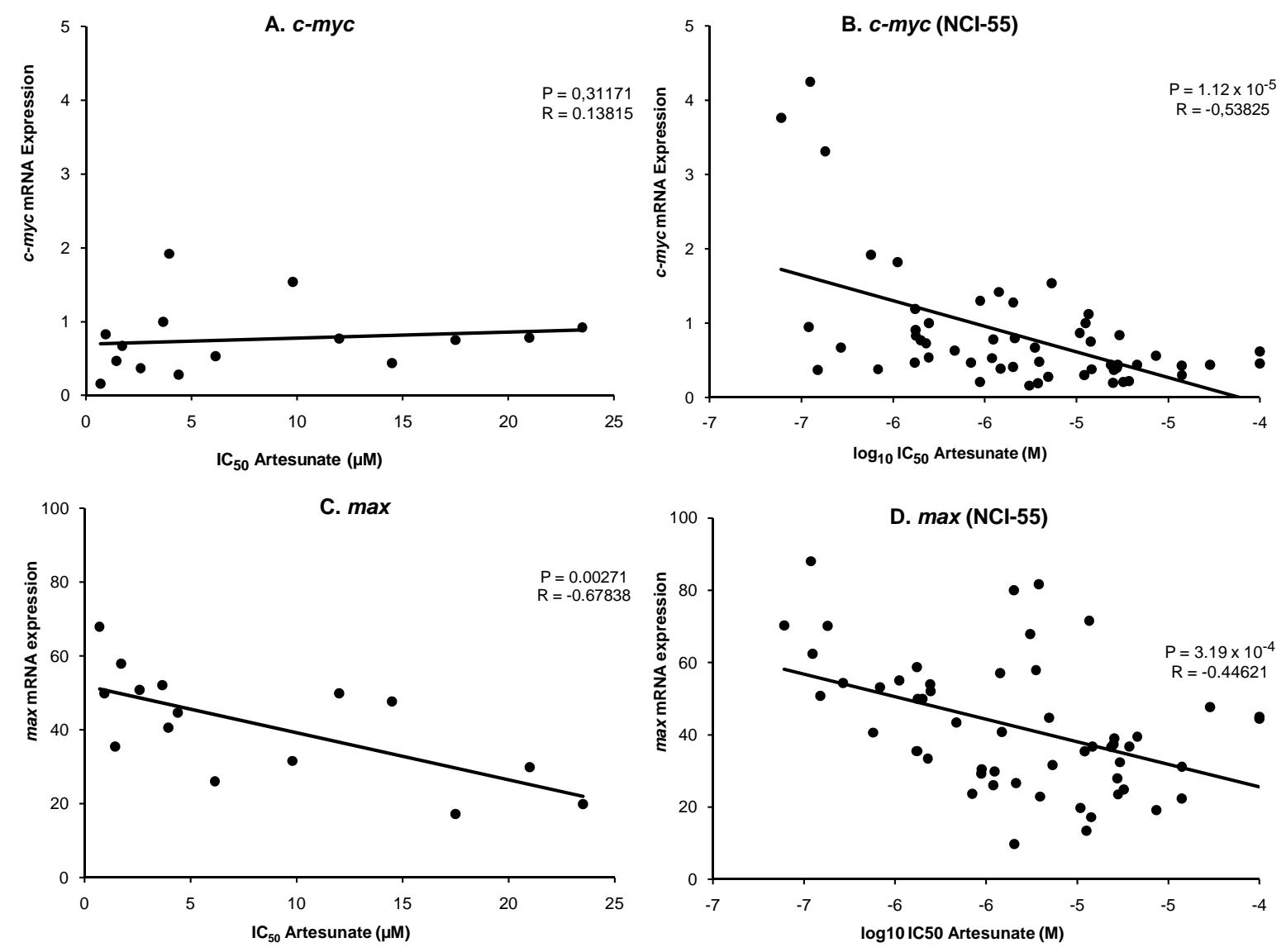

\section{Discussion}

\subsection{Identification of candidate genes by microarray and COMPARE analyses}

In the present investigation, we analyzed molecular determinants of response of tumor cell lines towards ART by means of microarray-based mRNA expression profiling and correlation of the $\mathrm{IC}_{50}$ 
values for ART of 39 tumor cell lines with the mRNA expression levels of these cell lines [16,17] by COMPARE analysis. This approach has previously been applied to unravel the mode of action of novel compounds [18-20]. Cluster and COMPARE analyses are also useful for comparing gene expression profiles with $\mathrm{IC}_{50}$ values for investigational drugs to identify candidate genes for drug resistance [21] and to identify prognostic expression profiles in clinical oncology [22].

We identified genes from diverse functional groups such as structural constituents of ribosomes (RPL29), ATP-binding cassette (ABC) transporters (ABCC3), kinases (PRKCSH, ITPK1, IKBKG , $D D R 2)$, cellular antioxidant defense and carcinogenesis (ATOX1), organization of actin cytoskeleton $(R R A S)$, regulation of carcinogenesis (SMAD3, WNT7A), cell adhesion and growth of malignant cells (ST8SIA1), apoptosis and cell proliferation (CSE1L), cell cycle progression and differentiation (S100A10) and metastasis (HMGA1, RPSA). Next, we classified those genes from the COMPARE analyses into genes correlating with sensitivity or resistance towards ART. ABCC3, ITPK1, IKBKG, SMAD3, WNT7A, ST8SIA1, S100A10, AKR1B1, AKR1C1 and ALDH3A1 were identified as genes correlating with ART resistance. Sensitivity genes for ART were ATOX1, RPL29, PRKCSH, DDR2, $R R A S, C S E 1 L, H M G A 1$ and RPSA. None of these genes have yet been reported to play a role for cellular response towards ART. Some of them, however, are involved in resistance to other drugs. This might also explain their role for response to ART.

Ribosomal proteins represent a classical mechanism of resistance towards antibiotics. Streptomycin resistance is based on the modification of an asparatic acid moiety in the ribosomal protein S12 [23]. RPL29 encodes a cytoplasmic ribosomal protein that is a component of the 60S subunit, and is also a peripheral membrane protein expressed on the cell surface that directly binds heparin. There is no evidence in the literature yet that cancer drug resistance is correlated with RPL29.

Multidrug resistance (MDR) is based on multiple mechanisms, one of which is drug efflux by ATPbinding cassette $(\mathrm{ABC})$ transporters. They are involved in the active transport of phospholipids, ions, peptides, steroids, polysaccharides, amino acids, bile acids, pharmaceutical drugs and other xenobiotic compounds [24]. In humans, 49 different $\mathrm{ABC}$ transporters have been identified, which are classified into seven sub-families (A-G) [25]. ABCB1 (P-glycoprotein, P-gp, MDR1), ABCC1-C6 (MRP1-6) and $A B C G 2$ (BCRP) confer resistance to cytostatic drugs of tumors and contribute to the failure of tumor chemotherapy [26]. With our pharmacogenomic approach, we found that high $A B C C 3$ expression was associated with resistance towards ART. $A B C C 3$ belongs to the ABC transporters and encodes multidrug resistance-associated protein 3 (MRP3). Over-expression of $A B C C 3$ results in high-level resistance to methotrexate [27]. Previously, we showed that ART is neither a substrate for $A B C B 1$ and $A B C G 2$ [28], nor an inhibitor of both $\mathrm{ABC}$ transporters [29]. It can be speculated that $A B C C 3$ might also affect susceptibility of cancer cells towards ART.

Protein kinases (PK) are fundamental for many cellular processes such as proliferation, apoptosis and differentiation [30]. Further, PKs are also involved in signal transduction related to resistance towards established anticancer drugs [31]. We previously reported that EGFR and its downstream kinases confer resistance towards ART [28,32]. In the present study, we identified four novel genes coding for kinases, which were correlated to response of tumor cells towards ART.

Copper is essential, although extremely toxic in high concentrations, intracellular copper concentrations are tightly controlled. Within the cell, copper is distributed by metallochaperones, 
including the small cytoplasmic protein $A T O X 1$ [33]. ATOX1 bas been implicated in resistance to cisplatin [34]. Likewise, binding of ART to ATOX1 might induce ART resistance.

The Y-Box-binding protein-1 (YBX1), a member of the cold-shock domain DNA- and RNA-binding protein superfamily, is known to mediate drug resistance. $Y B X 1$ is known to be involved in DNA repair, transcription, splicing, translation, and confers cisplatin resistance in several cancers [35]. YBX1 expression has been shown to have clinicopathological significance to be a potential predictive marker of recurrence in nasopharyngeal cancer patients [36]. Moreover, $Y B X 1$ regulates the expression of the multidrug-resistance gene $M D R 1 / A B C B 1$, which encodes P-glycoprotein [37,38]. Over-expression of P-gp is associated with MDR by reducing drug accumulation in resistant cells [39]. In breast cancer, $Y B X 1$ expression is discussed to be a potential marker of drug resistance and could possibly aid in selection of the appropriate adjuvant chemotherapy regime for breast cancers [40]. For NSCLC, nuclear $Y B X 1$ expression is an independent prognostic marker [37,38].

$A K R 1 B 1$ encodes one of three daunorubicin reductases, namely aldose reductase. Over-expression of $A K R 1 B 1$ results in drug resistance towards daunorubicin [41]. AKR1C1 is a member of the aldoketo reductase superfamily that is involved in the activation of carcinogenic polycyclic aromatic hydrocarbons [42]. Interestingly, transfection of AKRIC1 in NSCLC cells contributes to drug resistance towards cisplatin and adriamycin via the activation of PKC. AKR1Cl-associated drug resistance may be related to altered control of DNA repair and apoptosis [43].

$A L D H 3 A 1$ encodes an antioxidant enzyme (aldehyde dehydrogenase) with several postulated protective roles that include detoxification of peroxidic aldehydes and scavenging of free radicals. Its expression has been implicated in clinical resistance to cyclophosphamide [44]. In addition, $A L D H 3 A 1$ contributes to the multidrug resistance-conferring function of the metastasis gene metadherin [45]. These genes could provide new targets for overcoming ART resistance, although underlying mechanisms remain to be elucidated.

\subsection{Signaling pathway analyses}

To analyze whether the genes identified belong to certain signal transduction pathways, which may be relevant for mediating the cytotoxic effects of ART, we applied Ingenuity Pathway Analysis and found that TNF- and TP53- signaling pathways were affected.

The tumor necrosis factor (TNF) is a cytokine that is able to induce apoptotic cell death and to inhibit tumorigenesis. Also, TNF induces nuclear factor 'kappa-light-chain-enhancer' of activated Bcells $(\mathrm{NF}-\kappa \mathrm{B})$ activation [46]. Considering the fact, that chemotherapeutic agents also have the ability to induce NF- $\kappa \mathrm{B}$ activation through the up-regulation of anti-apoptotic gene products that leads to drug resistance [47], we conclude that TNF might play a role in ART resistance.

Since the early 1990s, the TP53 tumor suppressor gene has been suggested to be involved in drug resistance [48]. Studies over the past decade have provided stringent evidence linking mutations in TP53 with drug resistance to the anthracyclines but also to mitomycin in hematological malignancies and breast cancer [49]. In the present investigation, we showed that TNF- and TP53-signaling pathways might also be relevant for ART response rates of tumor cells.

We performed signaling pathway analysis to compute biological functions that are most probably affected by ART. Interestingly, lipid metabolism and drug metabolism were the second significantly 
important biological functions. Lipids are involved in the formation of biological membranes and the lipid composition of vesicles involved in membrane traffic [50]. Vesicular drug binding, processing and extrusion was hypothesized as a general mechanism involved in drug resistance [51]. Formation of membrane vesicles was proven for mitoxantrone resistance [52]. Based on our result, membrane vesicles for extrusion and exocytosis of chemotherapeutics might be one mechanism of ART resistance.

By signaling pathway analysis, we also determined potential mechanisms of toxicity, e.g. xenobiotic metabolism, oxidative stress, TGF- $\beta$ signaling and PXR/RXR activation. Epidermal growth factor (EGF) and its receptor (EGFR) as well as the EGFR-coupled Ras $>$ Raf $>$ MEK $>$ ERK pathway are known to affect the survival of cancer cells upon therapeutic treatment. Indeed, we observed that the Ras $>$ Raf $>$ MEK $>$ ERK pathway is an important signaling route for ART resistance [32]. Another downstream gene of EGFR, e.g., phosphatidylinositol 3'-kinase (PI3K)/AKT has been shown to contribute to cisplatin resistance by promoting cell proliferation and increasing drug metabolism and resistance to apoptosis [53,54]. In addition, EGFR differentially modulates the PI3K/AKT pathway in regulating tumor cell growth and dormancy [55]. Also, transforming growth factor-beta1 (TGF- $\beta 1$ ) plays an important role in drug resistance induced by glucocorticoids in ovarian cancer cells [56]. Cooperative signaling between EGFR and TGF- $\beta$ regulates tumor invasion, neo-angiogenesis and inflammation [57]. As signaling is an extension of EGFR, a contribution of TGF- $\beta 1$ in EGFR-related ART resistance can be hypothesized.

The pregnane $\mathrm{X}$ receptor $(\mathrm{PXR})$ /retinoid $\mathrm{X}$ receptor (RXR) heterodimer regulates a constellation of genes involved in xenobiotic detoxification, the cytochrome P450 (CYP) [58]. In particular, CYP3A is involved in the hepatic detoxification of more than $50 \%$ of prescription drugs [59]. As ART is a xenobiotic, PXR/RXR has to be taken into account as a mechanism of detoxification.

Among the pleiotropy of canonical pathways that might be affected by ART, five top pathways were identified by signaling pathway profiling: lipopolysaccharides (LPS)-stimulated MAPK signaling, apoptosis signaling, PI3K/AKT signaling, pyruvate metabolism, and angiopoietin signaling.

LPS activates the inducible nitric oxide synthase (iNOS) expression pathway and in this context, NO generation and signaling play a role in exhibiting cytotoxic activity of ART [60]. This is in concordance with the finding of the present study, that ART might affect LPS-stimulated MAPK signaling.

Research on apoptosis has increased substantially since the early 1990s. In the past, we showed that ART induced apoptosis in KG-1a leukemia cells [8], and that a number of apoptosis-regulating genes (LOC51272, CIDEB, PDCD2, BAG1, BAG3, MADD) correlated with cellular responses towards ART [28]. The present study reveals $C S E 1 L$ as apoptosis-regulating gene associated with cellular response towards ART. In an earlier study, we analyzed the role of ferrous iron in the cytotoxicity of artemisinins toward tumor cells. ART and ART plus ferrous iron induced apoptosis in CCRF-CEM cells [61]. Apoptosis by ART is mainly induced by the mitochondrial pathway via generation of reactive oxygen species (ROS) in leukemic T-cell lines, a mechanism different from doxorubicin [6]. The active moiety of ART is an endoperoxide bridge that generates carbon-centered free radicals and oxidative stress upon cleavage. Oxidative stress appears to be necessary for the antimalarial activity of ART and suggests that antioxidant defenses act in combination to affect the cellular response to ART 
[11]. Indeed, in the present study we observed correlations of oxidative stress and mitochondrial dysfunction to ART. This aspect still needs detailed elucidation in future.

Pyruvate supplies energy to cells in the citric acid cycle, and can also be converted to carbohydrates via gluconeogenesis, to fatty acids or energy through acetyl-CoA, to the amino acid alanine and to ethanol [62]. High concentration of pyruvate inhibits the activity of pyruvate dehydrogenase kinase (PDK) 1, -2, and -4, but not PDK3 [63]. Induction of PDK3 by hypoxia blocks the conversion of pyruvate to acetyl-CoA and reduces oxygen consumption. PDK3 may represent the critical molecule that controls the metabolic switch of cancer cells from oxidative phosphorylation to aerobic glycolysis (Warburg effect) [63]. Based on our present data, ART-induced over-expression of PDK3 may be a new mode of anti-cancer activity of ART.

Angiopoietin signaling was correlated with following genes: IKBKG, RRAS2, RRAS . IKBKG belongs to one of our identified four novel genes coding for kinases, which were correlated to response of tumor cells towards ART. RRAS regulates the organization of the actin cytoskeleton. Angiopoietininduced activation during tumor growth, development, and metastasis suggests that the ability to modulate the receptor-ligand interactions would have onco-therapeutical applications. In previous studies, we and others confirmed the anti-angiogenical effect of ART and its metabolite dihydroartemisinine [64]. Inhibition of angiogenesis may be a general mechanism of artemisinin derivatives to inhibit tumor growth in vivo [65]. This is in accordance to the present correlation of angiopoietin signaling with ART.

\subsection{Transcription factor downstream gene analyses}

It was a striking and surprising result that a considerable number of genes identified by microarray and COMPARE analyses are not linked to cancer biology, e.g. genes involved in the survival of cochlear outer and inner hair cells (SLC12A7), the active cellular uptake of carnitine (SLC22A5), regulation of sterol biosynthesis $(S C A P)$, the synthesis of asparagines $(A S N S)$ and regulation of gene expression $(U B B)$, do not have obvious links to tumor diseases. This poses the question, whether other mechanisms than activation of cancer-specific signaling pathways may contribute to mRNA expression profiles. We hypothesized that transcription factors may transcriptionally activate downstream genes at least partially independent of whether they belong to certain signaling routes. Hence, transcription factors active in ART-sensitive tumor cells regulate not only genes affecting ART sensitivity, but also genes unrelated to cellular response towards ART. This may explain, why we found many genes without obvious connection to cancer or drug response. Since c-Myc is known to affect downstream processes in tumor cells [16] and we previously reported that the expression of cMyc is correlated with sensitivity of cancer cells to ART [28], we took c-Myc as an example to further investigate this hypothesis. Therefore, we performed a gene promoter analysis of these genes, which were significantly correlated in our cell line panel with response to ART.

Indeed, the vast majority of genes contained one or more binding motifs in their promoters for cMyc. This result is conceivable with the fact that the expression of c-Myc and its dimerization partner, Max, significantly correlated with response of tumor cells to ART. Our explanation of these results is that the transcriptional regulation of downstream genes by c-Myc/Max determines cellular response towards ART. The c-Myc/Max-regulated genes may in part affect ART sensitivity. Another fraction of 
c-Myc-Max regulated genes might not causally be linked with cellular response to ART, but are differentially expressed in ART-sensitive and ART-resistant tumors. Another possibility is that the therapeutic potential of artemisinin-type drugs is much larger than malaria and cancer. Therefore, the molecular architecture of cells might be exploited to treat also other diseases by ART.

The gene with the highest potential binding sites for c-Myc, KRT4, belongs to the ART resistance genes and encodes a protein of the keratin gene family. The type II cytokeratins consist of basic or neutral proteins, which are arranged in pairs of heterotypic keratin chains co-expressed during differentiation of simple and stratified epithelial tissues. This type II cytokeratin is specifically expressed in differentiated layers of the mucosal and esophageal epithelia with family member KRT13. Mutations in these genes have been associated with White Sponge Nevus, characterized by oral, esophageal, and anal leukoplakia.

The gene with the second highest potential binding sites, SLC12A7, also belongs to the ART resistance genes. It encodes a potassium-chloride transporter, and has second highest number of potential binding sites for c-Myc. It mediates electroneutral potassium-chloride co-transport when activated by cell swelling. It may mediate $\mathrm{K}^{+}$uptake into Deiters' cells in the cochlea and contribute to $\mathrm{K}^{+}$recycling in the inner ear. It is important for the survival of cochlear outer and inner hair cells and the maintenance of the organ of Corti. In addition, it may be required for basolateral $\mathrm{Cl}^{-}$extrusion in the kidney and contribute to renal acidification.

Another gene associated with resistance towards ART, S100A10, has eight potential binding sites for c-Myc. It encodes a member of the S100 family of proteins. S100 proteins are localized in the cytoplasm and/or nucleus of a wide range of cells, and are involved in the regulation of a number of cellular processes such as cell cycle progression and differentiation. This protein may function in exocytosis and endocytosis. Because $S 100 A 10$ induces the dimerization of ANXA2/p36, it may function as a regulator of protein phosphorylation in that the ANXA2 monomer is the preferred target of tyrosine-specific kinases.

We also found genes associated with sensitivity towards ART with high numbers of binding sites for c-Myc, e.g. TIMM17A, ATOX1, TIMM17A, PRKCSH, RPL29 and YBX1. TIMM17A encodes translocase of inner mitochondrial membrane 17. It is an essential component of the TIM23 complex, a complex that mediates the translocation of transit peptide-containing proteins across the mitochondrial inner membrane. ATOXI encodes a copper chaperone that plays a role in copper homeostasis by binding and transporting cytosolic copper to ATPase proteins in the trans-Golgi network for subsequent incorporation into ceruloplasmin. This protein also functions as an antioxidant against superoxide and hydrogen peroxide, and therefore, may play a significant role in cancer carcinogenesis and may be important in cellular antioxidant defense. PRKCSH encodes the beta-subunit of glucosidase II, an N-linked glycan-processing enzyme in the endoplasmic reticulum. This acidic phosphoprotein is known to be a substrate for protein kinase C. Mutations in this gene have been associated with the autosomal dominant polycystic liver disease. RPL29 encodes a cytoplasmic ribosomal protein that is a component of the $60 \mathrm{~S}$ subunit. The protein belongs to the L29E family of ribosomal proteins. The protein is also a peripheral membrane protein expressed on the cell surface that directly binds heparin. $Y B X 1$ binds to splice sites in pre-mRNA and regulates splice site selection. It contributes to the regulation of translation by modulating the interaction between the mRNA and eukaryotic initiation factors (By similarity). Moreover, it binds to promoters that contain a Y-box (5'- 
CTGATTGGCCAA-3'), such as HLA class II genes. YBXI regulates the transcription of numerous genes and promotes separation of DNA strands that contain mismatches or are modified by cisplatin. Also, it has endonucleolytic activity and can introduce nicks or breaks into double-stranded DNA and therefore may play a role in DNA repair.

\section{Experimental}

\subsection{Drugs and reagents}

ART was obtained from Saokim Co. Ltd. (Hanoi, Vietnam). Dimethylsulfoxide (DMSO; Sigma) was used to dissolve and prepare stock solutions of ART $(20 \mathrm{mg} / \mathrm{mL})$.

\subsection{Cell lines}

The panel of cell lines for the present investigations consisted of 39 human tumor cell lines representing non-small cell lung cancer (A549, NIH-H23, NIH-460, WT-E, BH-E, SKLC-6, QU-DB), colon cancer (HT29, COLO205, WiDr, LoVo, DLD-1, HCT116, SW620, HCT15, BE, SW480, HCG2998, KM12) and ovarian carcinoma (OVCAR2, OVCAR3, OVCAR4, OVCAR5, OVCAR8, OVCAR10, 2008, C13, C30, C200, SKOV3, OAW42, UPN251, PEO1, PEO4, CP70, A1847, A2780, A2780-AD10, A2780-TX) [66]. Cell lines wree obtained from American Type Culture Collection (ATCC; Manassas, VA, USA) and used in passages 60-100. The human ovarian cancer cell lines contained highly cisplatin resistant cell lines of the A2780/C-series (C30 and C200) [67]. Furthermore, adriamycin A2780-AD10, and paclitaxel-resistant cells (A2780-TX) were used [67].

Cells were maintained at $37{ }^{\circ} \mathrm{C}$ in a humidified incubator containing $5 \% \mathrm{CO}_{2}$ in RPMI-1640 medium (Life Technologies, Grand Island, NY, USA) supplemented with $10 \%\left(\mathrm{vv}^{-1}\right)$ fetal calf serum (Atlanta Biologicals, Atlanta, GA, USA), $100 \mu \mathrm{g} \mathrm{mL}^{-1}$ streptomycin, $100 \mathrm{U} \mathrm{mL}^{-1}$ penicillin, $0.3 \mathrm{mg}$ $\mathrm{mL}^{-1}$ glutamine and $0.25 \mathrm{U} \mathrm{mL}^{-1}$ insulin (porcine).

\subsection{MTT assay}

Cytotoxicity in terms of $\mathrm{IC}_{50}$ values for the four platinum drugs were determined using the 3-(4,5dimethyl-thizol-2-yl)-2,5-diphenyltetrazolium bromide (MTT) assay [68]. Cells (100 - 4,000/well) were plated in $150 \mu \mathrm{L}$ of medium/well in 96-well microtiter plates. Following overnight incubation, cells were exposed to a range of drug concentrations. After $72 \mathrm{~h}, 40 \mu \mathrm{L}$ of $5 \mathrm{mg} \mathrm{mL}^{-1}$ MTT were added per well and the plates were incubated for $2 \mathrm{~h}$ at $37^{\circ} \mathrm{C}$. The cells were then lysed by adding $100 \mu \mathrm{L}$ of $20 \%(\mathrm{wv})$ sodium dodecyl sulphate (SDS), 50\% (vv) $N, N$-dimethylformamide ( $\mathrm{pH} 4.7$ ), and then incubating overnight at room temperature. The absorbance at $595 \mathrm{~nm}$ was determined using a Bio-Tek $\mathrm{EL}_{\mathrm{X}} 800$ microplate reader (Bio-Tek Instruments, Winooski, VT, USA). The reported values are the average of triplicate determinations made on at least two separate occasions.

\subsection{RNA isolation}

Total cellular RNA was extracted from the cell lines by a modification of the single-step method $[69,70]$ using guanidine isothiocyanate. RNA was precipitated from the aqueous phase by the addition 
of isopropanol. Following centrifugation, RNA pellets were washed with $75 \%$ ethanol, resuspended in DEPC-treated water and treated with DNase I. RNA integrity was assessed by ethidium bromide staining following agarose-gel electrophoresis and quantified by absorbance at $260 \mathrm{~nm}$. Samples were stored at $-80{ }^{\circ} \mathrm{C}$ under ethanol.

\subsection{Preparation of cDNA probes}

Total RNA $(2.0 \mu \mathrm{g})$ was combined in a $1.5 \mathrm{~mL}$ microcentrifuge tube with $10 \mu \mathrm{g}$ of oligo-dT (Research Genetics) in a final volume of $10 \mu \mathrm{L}$ and incubated at $70{ }^{\circ} \mathrm{C}$ for $10 \mathrm{~min}$ and placed on ice for $5 \mathrm{~min}$. The cDNA synthesis reaction contained a mixture of $6.0 \mu \mathrm{L}$ of $5 \times$ First Strand Buffer (Life Technologies), $1.0 \mu \mathrm{L} 100 \mathrm{mM}$ DTT, $1.5 \mu \mathrm{L}$ dA/dG/dT (10 mM each), $10 \mu \mathrm{L}\left[\mathrm{a}^{-33} \mathrm{P}\right] \mathrm{dCTP}(100 \mu \mathrm{Ci})$,

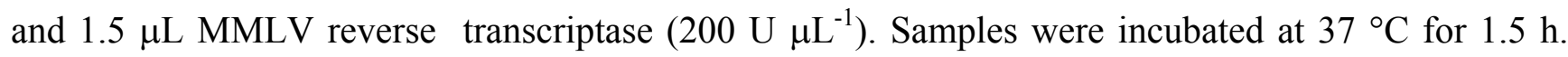
Nucleotides and unincorporated ${ }^{33} \mathrm{P}$ were removed by gel chromatography using Micro Bio-Spin 30 columns (Bio-Rad Laboratories, Hercules, CA, USA). The samples were denatured by incubating at $100{ }^{\circ} \mathrm{C}$ for $3 \mathrm{~min}$ and placed on ice.

\section{6. cDNA microarray screening}

Microarray analysis was carried out using the recommended procedure supplied by Research Genetics Inc. The Named Human Genes filters (GF211), which are spotted with 4132 cDNA elements, were pre-hybridized in $5 \mathrm{~mL}$ MicroHyb solution (Research Genetics) containing $5 \mu \mathrm{g}$ of poly-dA overnight at $42{ }^{\circ} \mathrm{C}$ in a hybridization oven (Model H010-1, Stovall Life Science Inc., Greensboro, NC, USA). The denatured probes were then added to this solution and incubated $14-18 \mathrm{~h}$ at $42{ }^{\circ} \mathrm{C}$. The membranes were washed briefly with $200 \mathrm{~mL}$ of wash buffer I $(2 \times \mathrm{SSC}, 1 \% \mathrm{SDS})$ at room temperature, followed by two $20 \mathrm{~min}$ washes with the same buffer at $50{ }^{\circ} \mathrm{C}$, and two washes with $200 \mathrm{~mL}$ of wash buffer II $(0.5 \times \mathrm{SSC}, 1 \% \mathrm{SDS})$ at $55^{\circ} \mathrm{C}$ for $20 \mathrm{~min}$. The filters were removed, immediately wrapped in plastic and imaged on a Storm 840 phosphorimager (Molecular Dynamics, Sunnyvale, CA, USA), following a 5-day exposure to the imaging plate. For reuse, membranes were stripped by incubating for $20 \mathrm{~min}$ in $0.5 \%$ (wv) SDS that had been brought to $100{ }^{\circ} \mathrm{C}$ and repeating. Stripped filters were reimaged following a $24 \mathrm{~h}$ exposure to insure complete removal of radioactivity.

\subsection{Data analyses}

The data obtained from the phosphorimager was analyzed using Pathways software (Research Genetics). This software utilizes the raw image obtained from the phosphorimager in order to align the image and determine expression values for all of the elements. The raw data were downloaded into Microsoft Excel for final analysis. Also, a signal-to-noise ratio was obtained for all of the hybridized filters by dividing the mean of the raw data by the background value. Only the hybridizations that yielded signal-to-noise ratios above 1.5 were used in the subsequent data analysis. In order to correct for background, the average value of the lowest $1 \%$ of the genes expressed for each sample was subtracted from each raw data point to obtain a background corrected expression value. The data were then normalized by subtracting the mean and dividing by the standard deviation of the expression values for the entire data set for each cell line (global means method). RNA from each cell line was 
subject to microarray analysis at least twice. The normalized data obtained from duplicated hybridizations were averaged to obtain a final data set. Reproducibility of the data was assessed by calculating a percent error $($ S.D./mean $\times 100)$ for each gene element.

The data were cropped to a final set of 2,000 elements by eliminating genes with relatively low expression and low standard deviation across the panel of cell lines. This was carried out by exemplarity measuring gene expression by quantitative 'real-time' PCR (qRT-PCR). We considered a gene 'validatable' if the Spearman and/or Pearson correlation coefficient was $\geq 0.6$ for the microarray/PCR data. A factor $(\mathrm{P})$ was calculated by multiplying the average of the expression of each gene for all the cell lines with the standard deviation. Genes with P-values below 100,000 could not be consistently validated by RTq-PCR and were eliminated. We also eliminated genes in which the median expression value across the cell lines was low (see Web Supplement for more detail).

The identification of candidate drug sensitivity/resistance genes was carried out by several statistical methods. Correlation coefficients (Pearson) were calculated for the expression of each gene relative to artesunate sensitivity for the entire panel of cell lines. The correlation coefficients were then ranked from highest to lowest and vice ver sa in order to obtain a list of genes associated with proliferation and/or platinum drug sensitivity. Information about genes was obtained by the web-based database GeneCards ${ }^{\circledR}$ that provides concise genomic, proteomic, transcriptomic and functional information on all known and predicted human genes (http://www.genecards.org/index.shtmL/).

\subsection{Statistical analyses}

COMPARE analyses were performed with software implemented into the web site of the NCI (http://dtp.nci.nih.gov). COMPARE analyses yielded rank-ordered lists of compounds. Every compound of the Standard Agent Database of the NCI was ranked for similarity between its modulation of in vitro cell growth patterns and the modulation of in vitro cell growth patterns of a selected seed or probe compound [71]. To obtain COMPARE rankings, a scaler index of similarity between the seed compound cell growth pattern and the pattern for each of the COMPARE database compounds was created. This methodology has previously been exploited to identify the presumable mode of action of investigational drugs by comparing their $\mathrm{IC}_{50}$ profiles of the NCI cell lines with those of drugs with well-established mechanisms of action [19]. Pearson's correlation test determined the correlation of rank positions of values. Ordinal or metric scaling of data is suited for the test and transformed into rank positions. There is no condition regarding normal distribution of the data set for the performance of this test. This test was implemented into the WinSTAT Program (Kalmia Co., Cambridge, MA, USA).

\subsection{Identification of signaling pathways}

The Ingenuity Pathway Analysis software (IPA) (Ingenuity Systems, Mountain View, CA, USA; www.ingenuity.com) was utilized to identify networks and pathways of interacting genes and other functional groups in genomic data. Using the IPA Functional Analysis tool, we were able to associate biological functions and diseases to the experimental results. Moreover, we used a biomarker filter tool and the Network Explorer for visualizing molecular relationships. 


\subsection{Binding motif analyses in gene promoters}

The ConSite program was used to detect binding sites of the transcription factor c-Myc in gene promoter sequences of the determined microarray analyses-based genes. ConSite is available at (http://www.phylofoot.org/consite/).

\section{Conclusions}

The application of microarray-based mRNA profiling and COMPARE analysis led to the identification of genes, whose expression was associated either with high $\mathrm{IC}_{50}$ values or low $\mathrm{IC}_{50}$ values for ART. Therefore, these genes may determine resistance or sensitivity of tumor cells towards ART. This viewpoint is conceivable for genes involved in ribosomal activity, drug transport, cellular antioxidant defense, apoptosis, cell proliferation, cell cycle progression etc. An investigation of underlying signal transduction pathways by the Ingenuity Pathway Analysis software suggested a role of the signaling pathways related to TNF and the tumor suppressor p53. On the other hand, there were genes without obvious functional link to cellular response to ART, such as genes either involved in the survival of cochlear outer and inner hair cells etc. We proved the hypothesis that ART might influence the activity of transcription factors, which regulate downstream genes involved or not involved in response of cancer cells towards ART. This would explain the identification of genes with and without obvious relation to the cytotoxic activity of ART by microarray and COMPARE analyses. Investigating the binding motifs for the transcription factors c-Myc and max we indeed found that 53 of 56 genes contained one or more binding sites for c-Myc/Max in their promoter sequences. We conclude that c-Myc and Max-mediated transcriptional control of gene expression might contribute to the therapeutic effects of ART in cancer cells, but may also confer unwanted side effects by affecting therapy-unrelated genes.

\section{Conflict of Interest}

The authors declare that there are no conflicts of interest.

\section{References}

1. Klayman, D.L. Qinghaosu (artemisinin): An antimalarial drug from China. Science 1985, 228, 1049-1055.

2. Tu, Y. The development of new antimalarial drugs: Qinghaosu and dihydro-qinghaosu. Chin. Med. J. (Engl.) 1999, 112 976-977.

3. Li, Y.; Wu, Y.L. How Chinese scientists discovered qinghaosu (artemisinin) and developed its derivatives? What are the future perspectives? Med. Trop. (Mars) 1998, 58, 9-12.

4. Efferth, T. Willmar Schwabe Award 2006: Antiplasmodial and antitumor activity of artemisininfrom bench to bedside. Planta Med. 2007, 73, 299-309.

5. Efferth, T.; Fu, Y.J.; Zu, Y.G.; Schwarz, G.; Konkimalla, V.S.; Wink, M. Molecular target-guided tumor therapy with natural products derived from traditional Chinese medicine. Curr. Med. Chem. 2007, 14, 2024-2032. 
6. Efferth, T.; Giaisi, M.; Merling, A.; Krammer, P.H.; Li-Weber, M. Artesunate induces ROSmediated apoptosis in doxorubicin-resistant T leukemia cells. PLoS One 2007, 2, e693.

7. Efferth, T.; Li, P.C.; Konkimalla, V.S.; Kaina, B. From traditional Chinese medicine to rational cancer therapy. Trends Mol. Med. 2007, 13, 353-361.

8. Efferth, T.; Rucker, G.; Falkenberg, M.; Manns, D.; Olbrich, A.; Fabry, U.; Osieka, R. Detection of apoptosis in KG-1a leukemic cells treated with investigational drugs. Arzneimittelforschung 1996, 46, 196-200.

9. Efferth, T. Microarray-based prediction of cytotoxicity of tumor cells to cantharidin. Oncol. Rep. 2005, 13, 459-463.

10. Efferth, T.; Dunstan, H.; Sauerbrey, A.; Miyachi, H.; Chitambar, C.R. The anti-malarial artesunate is also active against cancer. Int. J. Oncol. 2001, 18, 767-773.

11. Efferth, T.; Briehl, M.M.; Tome, M.E. Role of antioxidant genes for the activity of artesunate against tumor cells. Int. J. Oncol. 2003, 23, 1231-1235.

12. Efferth, T. Mechanistic perspectives for 1,2,4-trioxanes in anti-cancer therapy. Drug Resist. Updat. 2005, 8, 85-97.

13. Berger, T.G.; Dieckmann, D.; Efferth, T.; Schultz, E.S.; Funk, J.O.; Baur, A.; Schuler, G. Artesunate in the treatment of metastatic uveal melanoma--first experiences. Oncol. Rep. 2005, 14, 1599-1603.

14. Efferth, T. Molecular pharmacology and pharmacogenomics of artemisinin and its derivatives in cancer cells. Curr. Drug Targets 2006, 7, 407-421.

15. Kelter, G.; Steinbach, D.; Konkimalla, V.B.; Tahara, T.; Taketani, S.; Fiebig, H.H.; Efferth, T. Role of transferrin receptor and the $\mathrm{ABC}$ transporters $\mathrm{ABCB} 6$ and $\mathrm{ABCB} 7$ for resistance and differentiation of tumor cells towards artesunate. PLoS One 2007, 2, e798.

16. Scherf, U.; Ross, D.T.; Waltham, M.; Smith, L.H.; Lee, J.K.; Tanabe, L.; Kohn, K.W.; Reinhold, W.C.; Myers, T.G.; Andrews, D.T.; Scudiero, D.A.; Eisen, M.B.; Sausville, E.A.; Pommier, Y.; Botstein, D.; Brown, P.O.; Weinstein, J.N. A gene expression database for the molecular pharmacology of cancer. Nat. Genet. 2000, 24, 236-244.

17. Staunton, J.E.; Slonim, D.K.; Coller, H.A.; Tamayo, P.; Angelo, M.J.; Park, J.; Scherf, U.; Lee, J.K.; Reinhold, W.O.; Weinstein, J.N.; Mesirov, J.P.; Lander, E.S.; Golub, T.R. Chemosensitivity prediction by transcriptional profiling. Proc. Natl. Acad. Sci. USA 2001, 98, 10787-10792.

18. Paull, K.D.; Lin, C.M.; Malspeis, L.; Hamel, E. Identification of novel antimitotic agents acting at the tubulin level by computer-assisted evaluation of differential cytotoxicity data. Cancer Res. 1992, 52, 3892-3900.

19. Leteurtre, F.; Kohlhagen, G.; Paull, K.D.; Pommier, Y. Topoisomerase II inhibition and cytotoxicity of the anthrapyrazoles DuP 937 and DuP 941 (Losoxantrone) in the National Cancer Institute preclinical antitumor drug discovery screen. J. Nat. Cancer Inst. 1994, 86, 1239-1244.

20. Shi, L.M.; Myers, T.G.; Fan, Y.; O'Connor, P.M.; Paull, K.D.; Friend, S.H.; Weinstein, J.N. Mining the National Cancer Institute Anticancer Drug Discovery Database: cluster analysis of ellipticine analogs with p53-inverse and central nervous system-selective patterns of activity. Mol. Pharmacol. 1998, 53, 241-251.

21. Efferth, T.; Gebhart, E.; Ross, D.D.; Sauerbrey, A. Identification of gene expression profiles predicting tumor cell response to L-alanosine. Biochem. Pharmacol. 2003, 66, 613-621. 
22. Efferth, T.; Olbrich, A.; Bauer, R. mRNA expression profiles for the response of human tumor cell lines to the antimalarial drugs artesunate, arteether, and artemether. Biochem. Pharmacol. 2002, 64, 617-623.

23. Harris, E.H.; Burkhart, B.D.; Gillham, N.W.; Boynton, J.E. Antibiotic resistance mutations in the chloroplast 16S and 23S rRNA genes of Chlamydomonas reinhardtii: Correlation of genetic and physical maps of the chloroplast genome. Genetics 1989, 123, 281-292.

24. Higgins, C.F. Multiple molecular mechanisms for multidrug resistance transporters. Nature 2007, 446, 749-757.

25. Efferth, T. The human ATP-binding cassette transporter genes: From the bench to the bedside. Curr. Mol. Med. 2001, 1, 45-65.

26. Gillet, J.P.; Efferth, T.; Remacle, J. Chemotherapy-induced resistance by ATP-binding cassette transporter genes. Biochim. Biophys. Acta 2007, 1775, 237-262.

27. Kool, M.; van der Linden, M.; de Haas, M.; Scheffer, G.L.; de Vree, J.M.; Smith, A.J.; Jansen, G.; Peters, G.J.; Ponne, N.; Scheper, R.J.; Elferink, R.P.; Baas, F.; Borst, P. MRP3, an organic anion transporter able to transport anti-cancer drugs. Proc. Nat. Acad. Sci. USA 1999, 96, 6914-6919.

28. Efferth, T.; Sauerbrey, A.; Olbrich, A.; Gebhart, E.; Rauch, P.; Weber, H.O.; Hengstler, J.G.; Halatsch, M.E.; Volm, M.; Tew, K.D.; Ross, D.D.; Funk, J.O. Molecular modes of action of artesunate in tumor cell lines. Mol. Pharmacol. 2003, 64, 382-394.

29. Sertel, S.; Eichhorn, T.; Sieber, S.; Sauer, A.; Weiss, J.; Plinkert, P.K.; Efferth, T. Factors determining sensitivity or resistance of tumor cell lines towards artesunate. Chem. Biol. Interact. 2010, 185, 42-52.

30. Grant, S.; Qiao, L.; Dent, P. Roles of ERBB family receptor tyrosine kinases, and downstream signaling pathways, in the control of cell growth and survival. Front. Biosci. 2002, 7, d376-d389.

31. McCubrey, J.A.; Steelman, L.S.; Chappell, W.H.; Abrams, S.L.; Wong, E.W.; Chang, F.; Lehmann, B.; Terrian, D.M.; Milella, M.; Tafuri, A.; Stivala, F.; Libra, M.; Basecke, J.; Evangelisti, C.; Martelli, A.M.; Franklin, R.A. Roles of the Raf/MEK/ERK pathway in cell growth, malignant transformation and drug resistance. Biochim. Biophys. Acta 2007, 1773, 1263-1284.

32. Konkimalla, V.B.; McCubrey, J.A.; Efferth, T. The role of downstream signaling pathways of the epidermal growth factor receptor for Artesunate's activity in cancer cells. Curr. Cancer Drug Targets 2009, 9, 72-80.

33. Muller, P.A.; Klomp, L.W. ATOX1: a novel copper-responsive transcription factor in mammals? Int. J. Biochem. Cell Biol. 2009, 41, 1233-1236.

34. Boal, A.K.; Rosenzweig, A.C. Crystal structures of cisplatin bound to a human copper chaperone. J. Am. Chem. Soc. 2009, 131, 14196-14197.

35. Guay, D.; Evoy, A.A.; Paquet, E.; Garand, C.; Bachvarova, M.; Bachvarov, D.; Lebel, M. The strand separation and nuclease activities associated with $\mathrm{YB}-1$ are dispensable for cisplatin resistance but overexpression of YB-1 in MCF7 and MDA-MB-231 breast tumor cells generates several chemoresistance signatures. Int. J. Biochem. Cell Biol. 2008, 40, 2492-2507.

36. Tay, W.L.; Yip, G.W.; Tan, P.H.; Matsumoto, K.; Yeo, R.; Ng, T.P.; Kumar, S.D.; Tsujimoto, M.; Bay, B.H. Y-Box-binding protein-1 is a promising predictive marker of radioresistance and chemoradioresistance in nasopharyngeal cancer. Mod. Pathol. 2009, 22, 282-290. 
37. Shibahara, K.; Sugio, K.; Osaki, T.; Uchiumi, T.; Maehara, Y.; Kohno, K.; Yasumoto, K.; Sugimachi, K.; Kuwano, M. Nuclear expression of the Y-box binding protein, YB-1, as a novel marker of disease progression in non-small cell lung cancer. Clin. Cancer Res. 2001, 7, 3151-3155.

38. Gessner, C.; Woischwill, C.; Schumacher, A.; Liebers, U.; Kuhn, H.; Stiehl, P.; Jurchott, K.; Royer, H.D.; Witt, C.; Wolff, G. Nuclear YB-1 expression as a negative prognostic marker in nonsmall cell lung cancer. Eur. Respir. J. 2004, 23, 14-19.

39. Gottesman, M.M.; Pastan, I. Biochemistry of multidrug resistance mediated by the multidrug transporter. Ann. Rev. Biochem. 1993, 62, 385-427.

40. Huang, J.; Tan, P.H.; Li, K.B.; Matsumoto, K.; Tsujimoto, M.; Bay, B.H. Y-box binding protein, YB-1, as a marker of tumor aggressiveness and response to adjuvant chemotherapy in breast cancer. Int. J. Oncol. 2005, 26, 607-613.

41. Plebuch, M.; Soldan, M.; Hungerer, C.; Koch, L.; Maser, E. Increased resistance of tumor cells to daunorubicin after transfection of cDNAs coding for anthracycline inactivating enzymes. Cancer Lett. 2007, 255, 49-56.

42. Penning, T.M. Dihydrodiol dehydrogenase and its role in polycyclic aromatic hydrocarbon metabolism. Chem. Biol. Interact. 1993, 89, 1-34.

43. Wang, H.W.; Lin, C.P.; Chiu, J.H.; Chow, K.C.; Kuo, K.T.; Lin, C.S.; Wang, L.S. Reversal of inflammation-associated dihydrodiol dehydrogenases (AKR1C1 and AKR1C2) overexpression and drug resistance in nonsmall cell lung cancer cells by wogonin and chrysin. Int. J. Cancer 2007, 120, 2019-2027.

44. Sreerama, L.; Sladek, N.E. Primary breast tumor levels of suspected molecular determinants of cellular sensitivity to cyclophosphamide, ifosfamide, and certain other anticancer agents as predictors of paired metastatic tumor levels of these determinants. Rational individualization of cancer chemotherapeutic regimens. Cancer Chemother. Pharmacol. 2001, 47, 255-262.

45. Hu, G.; Chong, R.A.; Yang, Q.; Wei, Y.; Blanco, M.A.; Li, F.; Reiss, M.; Au, J.L.; Haffty, B.G.; Kang, Y. MTDH activation by $8 \mathrm{q} 22$ genomic gain promotes chemoresistance and metastasis of poor-prognosis breast cancer. Cancer Cell 2009, 15, 9-20.

46. Gilmore, T.D. Introduction to NF-kappaB: Players, pathways, perspectives. Oncogene 2006, 25, 6680-6684.

47. Bharti, A.C.; Aggarwal, B.B. Nuclear factor-kappa B and cancer: Its role in prevention and therapy. Biochem. Pharmacol. 2002, 64, 883-888.

48. Kellen, J.A. Molecular interrelationships in multidrug resistance (review). Anticancer Res. 1994, 14, 433-435.

49. Lonning, P.E. Genes causing inherited cancer as beacons to identify the mechanisms of chemoresistance. Trends Mol. Med. 2004, 10, 113-118.

50. Daum, G. Lipid Metabolism and Membrane Biogenesis ； Springer-Verlag: Berlin-Heidelberg, Germany, 2004.

51. Cornwell, M.M.; Safa, A.R.; Felsted, R.L.; Gottesman, M.M.; Pastan, I. Membrane vesicles from multidrug-resistant human cancer cells contain a specific 150 - to $170-\mathrm{kDa}$ protein detected by photoaffinity labeling. Proc. Nat. Acad. Sci. USA 1986, 83, 3847-3850. 
52. Dietel, M.; Arps, H.; Lage, H.; Niendorf, A. Membrane vesicle formation due to acquired mitoxantrone resistance in human gastric carcinoma cell line EPG85-257. Cancer Res. 1990, 50, 6100-6106.

53. Hennessy, B.T.; Smith, D.L.; Ram, P.T.; Lu, Y.; Mills, G.B. Exploiting the PI3K/AKT pathway for cancer drug discovery. Nat. Rev. Drug Discov. 2005, 4, 988-1004.

54. Zhang, L.; Huang, J.; Yang, N.; Greshock, J.; Liang, S.; Hasegawa, K.; Giannakakis, A.; Poulos, N.; O'Brien-Jenkins, A.; Katsaros, D.; Butzow, R.; Weber, B.L.; Coukos, G. Integrative genomic analysis of phosphatidylinositol 3'-kinase family identifies PIK3R3 as a potential therapeutic target in epithelial ovarian cancer. Clin. Cancer Res. 2007, 13, 5314-5321.

55. Humtsoe, J.O.; Kramer, R.H. Differential epidermal growth factor receptor signaling regulates anchorage-independent growth by modulation of the PI3K/AKT pathway. Oncogene 2009, 29, 1214-1226.

56. Chen, Y.X.; Wang, Y.; Fu, C.C.; Diao, F.; Song, L.N.; Li, Z.B.; Yang, R.; Lu, J. Dexamethasone enhances cell resistance to chemotherapy through increasing adhesion to extracellular matrix in human ovarian cancer cells. Endocr. Relat. Cancer 2009, 17, 39-50.

57. Samarakoon, R.; Higgins, C.E.; Higgins, S.P.; Higgins, P.J. TGF-beta1-Induced Expression of the Poor Prognosis SERPINE1/PAI-1 Gene Requires EGFR Signaling: A New Target for Anti-EGFR Therapy. J. Oncol. 2009, 2009, 342391.

58. Maglich, J.M.; Stoltz, C.M.; Goodwin, B.; Hawkins-Brown, D.; Moore, J.T.; Kliewer, S.A. Nuclear pregnane $\mathrm{x}$ receptor and constitutive androstane receptor regulate overlapping but distinct sets of genes involved in xenobiotic detoxification. Mol. Pharmacol. 2002, 62, 638-646.

59. Traber, M.G. Vitamin E, nuclear receptors and xenobiotic metabolism. Arch. Biochem. Biophys. 2004, 423, 6-11.

60. Konkimalla, V.B.; Blunder, M.; Korn, B.; Soomro, S.A.; Jansen, H.; Chang, W.; Posner, G.H.; Bauer, R.; Efferth, T. Effect of artemisinins and other endoperoxides on nitric oxide-related signaling pathway in RAW 264.7 mouse macrophage cells. Nitric Oxide 2008, 19, 184-191.

61. Efferth, T.; Benakis, A.; Romero, M.R.; Tomicic, M.; Rauh, R.; Steinbach, D.; Hafer, R.; Stamminger, T.; Oesch, F.; Kaina, B.; Marschall, M. Enhancement of cytotoxicity of artemisinins toward cancer cells by ferrous iron. Free Radical Biol. Med. 2004, 37, 998-1009.

62. Cody, G.D.; Boctor, N.Z.; Filley, T.R.; Hazen, R.M.; Scott, J.H.; Sharma, A.; Yoder, H.S., Jr. Primordial carbonylated iron-sulfur compounds and the synthesis of pyruvate. Science 2000, 289, 1337-1340.

63. Lu, C.W.; Lin, S.C.; Chen, K.F.; Lai, Y.Y.; Tsai, S.J. Induction of pyruvate dehydrogenase kinase-3 by hypoxia-inducible factor-1 promotes metabolic switch and drug resistance. J. Biol. Chem. 2008, 283, 28106-28114.

64. Chen, H.H.; Zhou, H.J.; Wang, W.Q.; Wu, G.D. Antimalarial dihydroartemisinin also inhibits angiogenesis. Cancer Chemother. Pharmacol. 2004, 53, 423-432.

65. Dell'Eva, R.; Pfeffer, U.; Vene, R.; Anfosso, L.; Forlani, A.; Albini, A.; Efferth, T. Inhibition of angiogenesis in vivo and growth of Kaposi's sarcoma xenograft tumors by the anti-malarial artesunate. Biochem. Pharmacol. 2004, 68, 2359-2366. 
66. Roberts, D.; Schick, J.; Conway, S.; Biade, S.; Laub, P.B.; Stevenson, J.P.; Hamilton, T.C.; O'Dwyer, P.J.; Johnson, S.W. Identification of genes associated with platinum drug sensitivity and resistance in human ovarian cancer cells. Br. J. Cancer 2005, 92, 1149-1158.

67. Johnson, S.W.; Swiggard, P.A.; Handel, L.M.; Brennan, J.M.; Godwin, A.K.; Ozols, R.F.; Hamilton, T.C. Relationship between platinum-DNA adduct formation and removal and cisplatin cytotoxicity in cisplatin-sensitive and -resistant human ovarian cancer cells. Cancer Res. 1994, 54, 5911-5916.

68. Hansen, M.B.; Nielsen, S.E.; Berg, K. Re-examination and further development of a precise and rapid dye method for measuring cell growth/cell kill. J. Immunol. Methods 1989, 119, 203-210.

69. Chomczynski, P.; Sacchi, N. Single-step method of RNA isolation by acid guanidinium thiocyanate-phenol-chloroform extraction. Anal. Biochem. 1987, 162, 156-159.

70. Chomczynski, P.; Mackey, K. Substitution of chloroform by bromo-chloropropane in the singlestep method of RNA isolation. Anal. Biochem. 1995, 225, 163-164.

71. Paull, K.D.; Shoemaker, R.H.; Hodes, L.; Monks, A.; Scudiero, D.A.; Rubinstein, L.; Plowman, J.; Boyd, M.R. Display and analysis of patterns of differential activity of drugs against human tumor cell lines: Development of mean graph and COMPARE algorithm. J. Nat. Cancer Ins $t$. 1989, 81, 1088-1092.

Sample Availability: Samples of ART are available from Saokim Co. Ltd. (Hanoi, Vietnam).

(C) 2010 by the authors; licensee MDPI, Basel, Switzerland. This article is an open-access article distributed under the terms and conditions of the Creative Commons Attribution license (http://creativecommons.org/licenses/by/3.0/). 